\title{
AYURLOG
}

National Journal of Research in Ayurved Science

http://www.ayurlog.com January-March: 2021|Volume: 09 $9^{\text {th }}$ |Issue: $1^{\text {st }}$

ISSN: 2320-7329

\section{Concept of Tantrayukti with special emphasis on Adhikarana Tantrayukti}

\section{Manasi Hanumant Rane**1, Ganesh Puradkar², Arun S. Dudhamal ${ }^{3}$}

1. P.G. Scholar, Department of Samhita and Siddhanta.

2. Associate Professor, Ayurved Samhita and Siddhant Dept.,

3. Associate Professor, Rognidan Dept.,

APM's Ayurved Mahavidyalaya, Sion, Mumbai, Maharashtra.

*Corresponding author: manasihra@ gmail.com

\section{ABSTRACT}

A cautious evaluation of Ayurveda treatises reveals that there is a comprehensive approach regarding research. Tantrayukti is the systemic approach of studying a science to interpret its correct unambiguous meaning for its practical application. Tantrayukti is tools of textual study, method of study and teaching. It present as framework which clears the appropriate meaning and help to understand the real sense of shloka. One should interpret the Samhita with the help of these tantrayukti to understand the science in an apparent way. Adhikaran Tantrayukti is one among the 40 tantrayukti explained by different acharyas. It is widely used by our acharyas while constructing the Samhita for easy understanding. Even in the field of research Adhikarana refer to the subject or area with which the researcher is going to deal with. This review article highlights the importance of Tantrayukti in explaining the samhitas and also the utility of Adhikaran
Tantrayukti in understanding of classical text and its importance in research.

KEYWORDS : Ayurveda, Tantrayukti, treatise, Adhikaran Tantrayukti.

\section{INTRODUCTION}

Ayurveda is a science of life which has holistic approach. It deals with the preventive as well as the curative aspects of disease by its own principles. Acharyas have used some methodology while composing the Shastra in the term of Sutra to put knowledge in the concise and precise manners. So this knowledge can't be perceived by everyone as its hidden. To understand this knowledge briefly ancient scholars followed various grammatical and compositional tools while writing their Samhita, and tantrayukti is one of them. Understanding of these techniques are inevitable for deeper study of Ayurveda. 
Adhikaran Tantrayukti, one among the 40 tantrayukti is important as it demonstrates the focal topic that the creator expects to explain in his treatise. But in the lenthy run on path of education and research in ayurveda, the necessity and utility of tantrayukti is the most ignored part. Hence this study has been undertaken to explain the utility of tantrayukti by giving special emphasis to Adhikaran Tantryukti.

\section{AIM AND OBJECTIVES}

1. To study the importance and utility tantrayukti as mentioned in different samhitas.

2. To study the Adhikaran tantrayukti in detail.

\section{MATERIALS AND METHODS}

Data of this literature is collected from different Ayurvedic Samhitas and their respective commentaries, various articles of different websites have been referred for the specific materials.

\section{REVIEW OF LITERATURE}

\section{Meaning of the word Tantrayukti}

Tantrayukti mentioned by different Acharyas -

\begin{tabular}{|r|c|c|c|c|c|}
\hline $\begin{array}{r}\text { Sr. } \\
\text { No. }\end{array}$ & Name of Tantrayuti & Charak & Sushrut & $\begin{array}{c}\text { Koutilya } \\
\text { Arthashastra }\end{array}$ & $\begin{array}{c}\text { Bhattar } \\
\text { Harishchandra }\end{array}$ \\
\hline 1. & Adhikaran & + & + & + & + \\
\hline 2. & Yoga & + & + & + & + \\
\hline 3. & Hetwartha & + & + & + & + \\
\hline 4. & Padartha & + & + & + & + \\
\hline 5. & Pradesha & + & + & + & + \\
\hline 6. & Uddesha & + & + & + & + \\
\hline 7. & Nirdesha & + & + & + & + \\
\hline 8. & Vakyashesha & + & + & + & + \\
\hline 9. & Prayojana & + & - & + & + \\
\hline
\end{tabular}

The term "tantra" has been derived from the word "tanu vistare" (tanu dhatu + strana pratyaya) meaning "tananam-vistaranamiti tantram" means detailed knowledge of the subject which can be elaborated in detail. The term ' $y u k t i$ ' is derived from the word samadyarthaka yuj dhatu + ktin pratyaya. Yukti is otherwise called yojana of meaning planning. Tantrayukti is described as the methodology and method that allows one to compose and interpret scientific treatises efficaciously and intelligently. In different words, it stands for the systemic strategy to a scientific difficulty and it permits one to elucidate in reality and get a definite meaning for its practical application.

\section{Reference of Tantrayukti in Ayurveda and} other literature

There is variation in the no. of Tantrayukti according to various Acharyas -

- Koutilya Arthashastra - 32

- Sushrut Samhita - 32

- Bhattar Harischandra - 40

- Charak Samhita - 36

- Ashtand Sangraha - 36

- Ashtang Hridaya (Arundatta) - 36

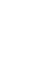




\begin{tabular}{|c|c|c|c|c|c|}
\hline 10. & Upadesha & + & + & + & + \\
\hline 11. & Apadesha & + & + & + & + \\
\hline 12. & Atidesha & + & + & + & + \\
\hline 13. & Arthapatti & + & + & + & + \\
\hline 14. & Nirnaya & + & + & - & + \\
\hline 15. & Prasanga & + & + & + & + \\
\hline 16. & Ekanta & + & + & + & + \\
\hline 17. & Anekanta & + & + & - & + \\
\hline 18. & Apavarga & + & + & + & + \\
\hline 19. & Viparyaya & + & + & + & + \\
\hline 20. & Poorvapaksha & + & + & + & + \\
\hline 21. & Vidhana & + & + & + & + \\
\hline 22. & Anumata & + & + & + & + \\
\hline 23. & Vyakhyana & + & + & + & + \\
\hline 24. & Samshaya & + & + & + & + \\
\hline 25. & Atikrantavekshana & + & + & + & + \\
\hline 26. & Anagatavekshana & + & + & + & + \\
\hline 27. & Swasandnya & + & + & + & + \\
\hline 28. & Uhya & + & + & + & + \\
\hline 29. & Samucchaya & + & + & + & + \\
\hline 30. & Nidarshana & + & + & + & + \\
\hline 31. & Nirvachana & + & + & + & + \\
\hline 32. & Sanyoga & + & + & - & + \\
\hline 33. & Vikalpa & $+\pi$ & $2 \pi+$ & + & + \\
\hline 34. & Pratyutsara & $+1-1$ & $Q 1+-$ & - & + \\
\hline 35. & Uddhara & +2010 & Dow-10ue & Tolse - & + \\
\hline 36. & Sambhava & + & - & - & + \\
\hline 37. & Pariprashna & - & - & - & + \\
\hline 38. & Vyukrantha abhidana & - & - & - & + \\
\hline 39. & Vyakarana & - & - & - & + \\
\hline 40. & Hetu & - & - & - & + \\
\hline 41. & Upamana & - & - & + & - \\
\hline 42. & Niyoga & - & - & + & - \\
\hline
\end{tabular}

\section{Utility and Importance of Tantrayukti}

All the Acharyas have explained about the need and utility of Tantrayukti from which one can understand its importance.

- Shastradhigama: proper understanding of Ayurveda. Because only proper understanding helps to preserve health and to cure illness. Improper awareness is potentially dangerous.

- Prabodhanam Ambujavanasyarka: The essence of Ayurvedic texts is elaborated, just as the lotus blooms, in sunshine, with Tantrayukti.

- Prakashanam Padeepo Veshmano: With Tantrayukti, the sense of challenging 
subjects becomes lucid, just as a light eliminates darkness in the house.

- Anuktartha Jnanartham: Tantrayukti makes it possible to understand even the hidden meanings that are unsaid.

- Aashu anyashatraprabodhanam: Not only Ayurveda, but one is able to understand other allied sciences by learning Tantrayukti as well.

- Swavakya siddhyartham: The interpretations drawn with the aid of Tantrayukti explain the scientific discourse's claims.

- Asadvadi Vakya patishedham: The arguments of those who misunderstand texts can be refuted in a scientific debate with the aid of Tantrayukti.

While going through the Samhitas one could understand some points are Avyakta (unclear), Leshokta (briefly explained), Leena (hidden), Vyatyasa (difference of opinion) etc. But all these points are to be made clear and understood by an intelligent physician with the help of Tantrayukti.

\section{Adhikaran Tantrayukti}

Adhi $+k r u+l y u t=$ adhikaran

Adharoadhikaranam |

Definition of Adhikaran Tantrayukti according to different Acharyas

Adhikarana is the subject about which something is spoken of. For example-on (the subject of) Rasa or on (the subject of) Dosha.

A chapter of a particular topic or subject is known as Adhikaran. The subject matter taken as the main topic is described in detail in the particular Adhikaran. E.g., The chapter that describes a roga (disease) is named by particular disease - rogadhikara viz; jwaradhikar, pramehadhikar.

The author aims to clarify the central themes in a treatise written by the author. The key subject matter for which every text and chapter is built and for which the subject can be automatically acquired by speech is called adhikarana tantrayukti. In a particular adhikara question, there may be one or more restricted adhikarana.

It is claimed, for example, that this Ayurvedic treatise is provided to prevent and cure diseases that are impediments to the path of a person willing to perform justly in the sense of duties. Here the illnesses, the treatises, etc. constitute the adhikara or the central theme or an adhikarana of Charak samhita to obtain longevity of life (dirghamjivita).

Adhikarana tantrayukti can be subtitled in five types as below-

1. Shastra adhikaran - ayurveda shastra is present in order to prevent and cure

diseases and obtained longevity of life to perform righteous thing on the context of duties.

2. Sthana adhikaran - Adhikarana of Chikitsa sthana of Charak Samhita is stated by Chakrapani is a patient who are not having sign and symptoms of arishta lakshana treatment of those are mentioned here which endows the physician with virtue, wealth and reputation in the society. So the chikitsa sthana 
deals with the methods to be followed for the treatment of such curable patients.

3. Adhyaya adhikaran - there is separate own Adhikarana of each adhyaya of Chikitsa sthan of charak samhita.

4. Prakaran adhikaran - according to the variation in nidan panchaka of every diseases and in base of that line of treatment of every diseases are explained in different point of view, according to various stages of diseases.

5. Vakya adhikaran - every statement/sentence/ shloka has its own Adhikarana.

\section{Importance of Adhikaran Tantrayukti in understanding Samhitas}

Intention of composition of group of verses is Adhikaran Tantrayukti. For example, Ayurved science is originated for the sake of roga (diseases); hence roga is adhikaran of Ayurved science.

Ayurved Samhitas are the best example of Adhikaran Tantrayukti. Each Samhita has specific adhikarana such as adhikarana of Sushruta Samhita is Shalyatantra i.e. surgery; adhikaran of Kashyap Samhita is Balaroga. Because of this it is very easy to understand the perticular topic from the entire Samhita.

Some examples of Adhikaran Tantrayukti in Charak Samhita

Its described in gulma chikitsa that while treating the pittaja gulma in a specific condition explained in charaka says that its responsibility of physician(surgeon) belonging to the Dhanwantari school who are well experience practically also in various aspect of surgery that is necessary for curing this disease. Here Charaka samhita is kayachikitsa pradhan so the treatment regarding surgical point of view is not the adhikarana of charaka so without crossing its adhikarana, charaka mentioned shalya adhikarana to the Dhanvantariya School which deals with the surgery.

In the treatment of Prameha Chikitsa, the treatment of Prameha Pidaka which is explained Roga Chatushka but treatment of this prameha pidaka is within the scope of surgeons and not the physicians Charaka deals with the medicine and not the surgery. Therefore, only line of treatment of this condition is indicated here and details are left to surgeons. So it is not the adhikarana of caraka samhita to go into the details of a subject and not explained in detail.

\section{Applicability in Research}

Adhikarana refers to the name of the topic/subject that is taken up for the study i.e. subject matter. It indicates the central theme that the author intends to expound in his treatise. In the field of research, Adhikarana refers to the subject or the area with which the researcher is going to deal with. The primary and one of the crucial necessities of the research process is to delineate the research study area clearly which helps to decide the boundaries of research. While selecting the topic, a researcher is advised to consider few things like the area of interest, upcoming trends, and burning issues in the society or something else in which he is compatible. 
In a nutshell, the topic for the research should be FINER i.e. feasible, interesting, novel, ethical and relevant.

\section{CONCLISION:-}

To understand the true meaning of Samhitas, Tantrayuktis are necessary and basic techniques. A good knowledge of these methods helps to understand the texts in correct perspective as the author has intended without such a knowledge there is risk of misinterpretation. A researcher can re-established or explore a new fact in literary research with the help of various tantrayuktis. Adhikaran tantrayukti is one of the important Tantrayukti using which the samhitas are made. Because of this it is easy to search specific topic in the treatise. It is the task of the scholars to disclose those valuable concepts contained in the treasure house of information.

\section{REFERENCES:}

1. Susruta, Susruta Samhita, Ayurveda Tattva Sandipika Hindi Commentary of Kaviraj Dr. Ambikadutta Shastri,
Varanasi, Chaukhamba Prakashan, 2013, Uttaratantra.

2. Charka, Yadavaji Trikamaji Charak Samhita of Agnivesha. Chakrapani commentary Varanasi; Chaukhamba Sanskrit Prakashan; Reprint 2014.

3. Brahmanand Tripathi Ashtang Hridayam Sutra Sthana. Chaukhamba Sanskrit Prakashan; 2014.

4. Vd. Tarachand Sharma, Ayurvediya Padarth Vigyan. The Health Sciences Publisher; 2018.

5. Acharya Sushruta. Sushrut Samhita eith Nibandha Sangraha Commentry by Dalhana and Nyayachandrika Panjika by Gayadasa, Yadavaji Trikamaji; Chaukhamba Surbharati Prakashan; Reprint 2014.

6. Lakshmidhar Dwivedi. Ayurveda ke mool Siddhant evum unki upadeyata. Chaukhamba Krishnadaas Academy; 2009.

7. Tripathi Ravidutta, Padarth Vidnyan, Choukhamba Surbharati Academy, Varanasi, Reprint, 2006.

Conflict of Interest: Non
Cite this article:
"Concept of Tantrayukti with special emphasis on Adhikarana Tantrayukti."
Manasi Hanumant Rane, Ganesh Puradkar, Arun S. Dudhamal
Ayurlog: National Journal of Research in Ayurved Science- 2021; (09) (01):01-06

